\title{
The Study of Ear Keloids by Surgical Excision with Fillet Flap in a Single Institution
}

\author{
Choong Jae Kim ${ }^{\mathbb{D}}$, Hoon Choi ${ }^{\mathbb{D}}$, Chan Ho Na ${ }^{\mathbb{D}}$, Bong Seok Shin $\mathbb{D}^{\mathbb{D}}$, and Min Sung Kim \\ Department of Dermatology, Chosun University School of Medicine, Gwangju, Korea \\ 단일 기관에서 필렛피판을 이용한 귀 켈로이드 수술 치료에 대한 연구 \\ 김충재 · 최 훈 · 나찬호 · 신봉석 · 김민성 \\ 조선대학교 의과대학 피부과학교실
}

Received September 3, 2019

Revised October 21, 2019

Accepted October 23, 2019

Address for correspondence

Min Sung Kim, MD, PhD

Department of Dermatology,

Chosun University

School of Medicine,

365 Pilmun-daero, Dong-gu,

Gwangju 61453, Korea

Tel $+82-62-220-3130$

Fax $+82-62-222-3215$

E-mail kimminsung@chosun.ac.kr
Background and Objectives Keloids are benign dermal fibrous growth and excessive collagen deposition that occur usually after trauma or surgery. In the treatment of keloids, the recurrence rate is relatively high after surgical excision. Fillet flap is known to be a good surgical method for keloid lesions. The purpose of this study is to find out manifestation and compare the results of ear keloids after the surgery by fillet flap.

Subjects and Method We retrospectively evaluated 22 patients with ear keloids $(n=31)$ who underwent core excision with fillet flap at the Department of Dermatology, Chosun University Hospital from May 2010 to June 2018.

Results With the 22 of treated patients and 31 ear keloid lesions, the average size of keloid lesions was $0.75 \times 1.05 \mathrm{~cm}^{2}$. The frequencies of occurrence with respect to the location of keloids according to the anatomical structure of the ear were 12 lobule $(38.7 \%)$, 17 helix $(54.8 \%)$, 1 antihelical fold $(3.2 \%)$, and 1 postauricle (3.2\%), respectively. There were 14 lobular types (45.2\%), 9 dumbbell types (29.0\%), 5 button types (16.1\%), and 3 wrap-around type $(9.7 \%)$. Recurrence was found in 8 keloid lesions $(25.8 \%)$ and 5 patients $(22.7 \%)$ after the surgery. Earlobe lesions and dumbbell shaped recurred with the highest recurrence rate. Among the 5 patients who relapsed, 4 had family history of keloids.

Conclusion The earlobe and dumbbell shaped types showed the highest recurrence rate and family history was also an important risk factor for recurrence. Also, surgical excision with fillet flap can be very effective and is a good way to treat ear keloids.

Korean J Otorhinolaryngol-Head Neck Surg 2020;63(7):301-7

Key Words Ear · Flap · Keloid · Surgery.

\section{서 론}

켈로이드는 외상, 염증, 화상 등에 의한 피부 손상 후 조직 의 복구 과정에서 손상받은 부위보다 넓게 성장하는 반흔성 조직으로, 조직학적으로 진피 내 섬유모세포가 비정상적으로 증식하고 아교섬유와 당단백질이 과축적되어 발생하게 된

This is an Open Access article distributed under the terms of the Creative Commons Attribution Non-Commercial License (https://creativecommons.org/licenses/by-nc/4.0) which permits unrestricted non-commercial use, distribution, and reproduction in any medium, provided the original work is properly cited.
다. 켈로이드는 시간이 경과함에 따라 색조가 진해지고 가 려움증이나 동통 및 압통이 동반될 수 있어 생활에 불편감을 줄 수 있고, 미용적인 문제를 야기하기에 적극적인 치료를 필 요로 하는 경우가 많으나 현재까지 $100 \%$ 확실한 치료법이나 재발을 막을 수 있는 효과적인 방법이 없으며 수술적 처치 및 다양한 처치에도 높은 재발율을 보인다. ${ }^{2}$ 현재 사용되는 치 료로는 다양한 방법의 수술적 절제, 스테로이드 및 5-fluorouracil, mitomycin-C, bleomycin 등의 병변 내 주사, 압박 요 법, 방사선 조사, 레이저 치료, 여러 치료의 병합 요법 등이 보 
고되었으며 이 중 스테로이드 병변 내 주사가 오랜 기간 사용 되어 왔으며 가장 흔히 시행되는 치료법이다. ${ }^{3)}$ 특히 귀 켈로이 드는 눈에 잘 띄는 위치와 여성에게 호발한다는 점에서 외래 에서 쉽게 접하는 질환이지만 스테로이드 단독 치료로는 만 족할 만한 효과를 얻기 어려운 경우가 많고, 수술적 제거 후 재발 방지를 위한 보조 치료가 효과적이라는 보고가 많았다. 저자들은 국내 문헌검색에서 수술과 병합 요법에 대한 보조 및 비교분석에 대한 연구를 많이 찾아 볼 수 있었으나 귀 켈 로이드에 대한 역학 및 필렛피판(fillet flap)에 대한 연구가 부 족한 것으로 보여 이에 대해 고찰하고자 하였다.

\section{대상 및 방법}

\section{연구 대상}

2010년 5월 2018년 6월까지 약 8년간 본 과에 내원하여 귀 켈로이드로 진단받고 입원하여 수술방에서 필렛피판을 이용 하여 외과적 절제 수술을 받은 22명의 환자를 대상으로 하였 다. 수술 방법으로는 켈로이드 덩어리를 그 위의 피부와 박리 한 후 제거하고, 피하조직의 봉합 없이 피부를 트리밍(trimming) 시행 후, 장력을 최소화하여 봉합하는 필렛피판(fillet flap)을 사용하였다. 본 연구는 본원의 임상시험연구심사위원 회(Institutional Review Board)의 연구 승인을 받았다(IRB No. 2019-08-003-001).

\section{수술 방법}

\section{수술 전 준비}

환자는 통원센터를 통해 입원하여 수술복으로 갈아입고 수술 동의서를 받은 후 수술방으로 들어와 침대에 누워 수술 받을 자세를 취한다. 환자의 산소포화도와 심박수를 측정할 수 있도록 모니터링에 연결하고 수술할 귀 병변이 천장을 향 하도록 얼굴을 돌리고 바셀린 거즈로 외이도를 막아 소독 시 포타딘액이 귀 안쪽으로 들어가지 않도록 하며, 귀 주위와 이 마로 머리카락이 수술모자 밖으로 나오지 않도록 2인치 플라 스터로 정리를 한 후 켈로이드 병변 주위로 국소마취(1\% 리도 카인 1:100000 에피네프린)액을 사용하여 국소마취를 시행 하였다. 에피네프린의 혈관 수축 효과를 약 10 분간 기다리는 동안 귀 켈로이드 병변과 그 주위 얼굴 전체를 포타딘으로 소독한 후 소독된 사각포를 이용하여 수술 부위만 들어나게 하였다.

켈로이드 병변 제거 및 재건 수술

켈로이드 병변에 절개선을 디자인한 후 15 번 수술용 메스
를 사용하여 피부를 얇게 절개한 후 켈로이드 덩어리 주위를 싸고 있는 피부의 표피와 진피 상층부 약간만을 남기면서 피 부만 얇게 박리하는 필렛피판을 시행하면서 켈로이드 덩어리 는 완전히 제거했다(Fig. 1). 켈로이드 덩어리가 완전히 잘 제 거되었는지 여부는 촉진을 통해 남아 있는 귀 조직이 부드럽 고 출혈이 잘 조절되는가를 확인함으로써 알아보았다. 전방 또는 후방 켈로이드의 경우, 켈로이드를 필렛피판으로 벗겨낸 피부를 트리밍 후 6-0 프롤린(prolene)실로 봉합하였다. 관통 형의 '아령(dumbbell)' 모양 켈로이드 병변은 중간의 연골을 일부 자르는 작업을 수행하였으며, 피하 봉합은 사용하지 않 았다.

\section{드레싱}

수술 후 드레싱은 폼 제제인 메필렉스 보더(Mepilex ${ }^{\circledR}$ Border, Mölnlycke Health Care AB, Göteborg, Sweden)를 사 용하여 수술 병변에 최대한 압박이 되도록 붙였으며 수술 당 일 하루는 환자 스스로 압박하도록 교육을 시켰다. 스테로이 드 주사, 압력 장치 또는 방사선 조사와 같은 다른 수술 중 또는 수술 후 예방 절차나 병합 요법은 사용하지 않았다. 검 체는 병리적 평가를 위해 병리학과로 보내졌으며 모든 경우에 켈로이드로 진단되었다. 수술 후 1주째 부분 실 제거(partial stitch out), 2주째 나머지 실 전체 제거(total stitch out)를 시 행하였다.
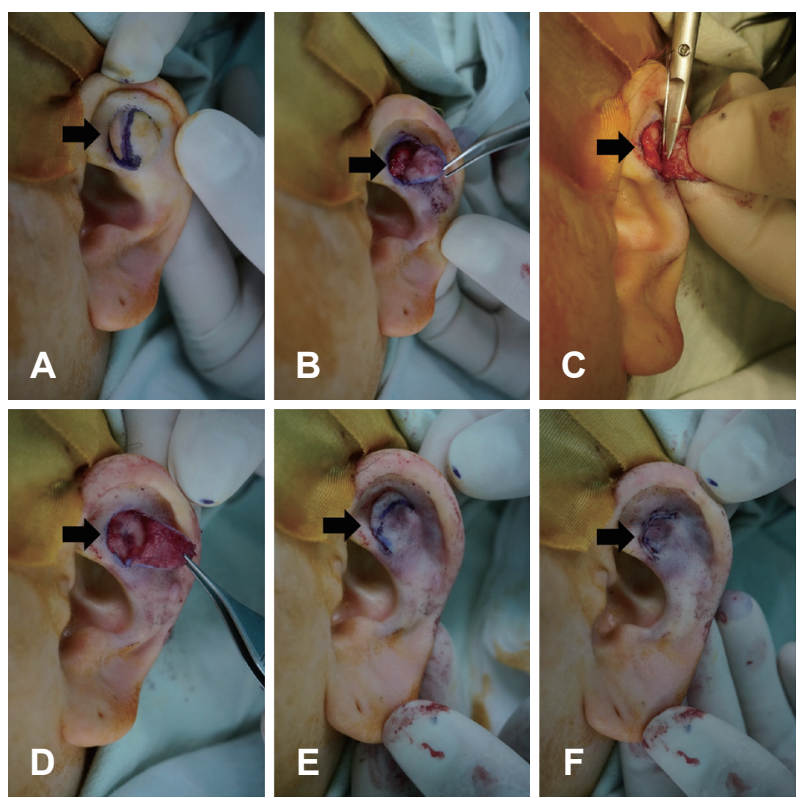

Fig. 1. Fillet flap procedure. Design an incision line for keloid fillet flap (A). Elevate the keloid fillet flap and remove the keloid mass (B). Remove the keloid completely and perform trimming (C). Showing complete removal of keloid mass (D). Trim the redundant keloid fillet flap (E). A state of completed suture (F). 


\section{연구 방법}

대상 환자의 의무기록 및 치료 전후의 사진을 후향적으로 조사하였으며, 환자의 나이, 성별, 켈로이드 병변의 크기, 발생 부위 및 귀 위치, 임상 형태, 발병 연령 및 내원 연령, 기저질 환, 켈로이드 가족력, 발생 원인, 동반 증상, 내원 전 치료 종 류 및 수술 후 재발 여부에 대해 조사하였다. 더불어 귀 켈로 이드 재발 환자의 특징을 비교하기 위해 재발 환자의 나이, 병 변의 크기, 재발 병변의 위치 및 형태, 발병 연령 및 내원 연 령, 동반증상과 재발 병변의 크기, 그리고 재발 후 시행한 처 치에 대해 조사하였다. 외래 추적 관찰은 수술 후 $1,2,6$ 주 간 격으로 세 번을 기본으로 하였으며 재발 여부는 외래 추적 관찰이나 전화로 재확인하였다. 재발 기준은 주변 피부보다 딱딱하게 다시 올라와 손으로 만져지거나 육안상 확인할 수 있는 경우로 하였다.

\section{통계학적 분석}

모든 통계 분석은 SPSS ver. 13.0 for windows(SPSS Inc., Chicago, IL, USA)를 사용하였으며, 치료군 간의 차이를 비 교하기 위해 피어슨의 카이 제곱 검정(Pearson's chi square test)을 이용하였다. 모든 통계량은 유의수준( $p$-value) 0.05 이하로 검정하였다.

\section{결 과}

\section{환자의 임상적 특징: 연구 대상, 성별 및 연령 분포, 발생원인}

전체 환자 22명 중 성별은 남성 3명(13.6\%), 여성 19명(86.4\%) 이었으며, 내원 시 연령 분포는 16 45세 사이로 평균 연령은 $24.9 \pm 6.5$ 세(최소 16 세, 최대 45 세)였다. 22명의 환자 중 수술 한 켈로이드 병변은 총 31 개 병변으로 오른쪽 귀에 켈로이드 가 있었던 환자는 7명(31.8\%), 왼쪽 귀 10명(45.5\%), 양쪽 귀 5 명(22.7\%)이었다. 오른쪽 귀의 병변은 15 개(48.4\%), 왼쪽 귀 의 켈로이드 병변은 16 개(51.6\%)였다. 귀 켈로이드의 발생 원 인은, 22명 중 21명(95.5\%, 남: 2명, 여: 19명)은 귀걸이 착용 을 위한 피어싱 이후에 발생하였으며 나머지 1 명 $4.5 \%$, 남 1 명)은 귀 부위 교통사고로 인한, 외상 후 발생한 열상 봉합 으로 인해 발생하였다(Table 1).

\section{켈로이드 임상적 특징: 위치, 크기, 형태, 가족력,} 기저질환 및 동반 증상

수술받은 귀 켈로이드 병변 31 개의 평균 크기는 $0.75 \times$ $1.05 \mathrm{~cm}^{2}$ 였으며, 가장 작은 병변 $0.2 \times 0.2 \mathrm{~cm}^{2}$ 부터 가장 큰 병변 $1.5 \times 2.5 \mathrm{~cm}^{2}$ 크기로 다양하였고, 가로 직경 대 세로 직
경의 평균비는 $1: 1.4$ 로 세로 길이가 $40 \%$ 정도 더 길었다. 귀 의 해부학적 구조에 따른 켈로이드 발생 위치는 이수(lobule, earlobe) 12개(38.7\%), 이륜(helix) 17개(54.8\%), 주상와(antihelical fold, scapha) 1개(3.2\%), 대이륜(antihelix) 0개(0.0\%), 이후방(postauricular) 1개(3.2\%)였다. 이 중 귀 뒷쪽으로 켈로 이드가 발생한 경우가 12 개(38.7\%)였으며 후방이륜(posterior helix)이 11개, 이후방(posterior helical fold)이 1개였다.

Table1. Characteristics of the keloids and patients

\begin{tabular}{|c|c|}
\hline Characteristics & $\begin{array}{c}\text { Total } \\
(n=22, \text { keloid }=31)\end{array}$ \\
\hline \multicolumn{2}{|l|}{ Sex, n (\%) } \\
\hline Male & $3(13.6)$ \\
\hline Female & $19(86.4)$ \\
\hline \multicolumn{2}{|l|}{ Age $(n=22$, years $)$} \\
\hline Onset & $22.3 \pm 5.3$ \\
\hline Surgery & $24.9 \pm 6.5$ \\
\hline \multicolumn{2}{|c|}{ Keloid in direction $(n=22$, keloid=31), $n(\%)$} \\
\hline Rt. ear & $7(31.8), 15(48.4)$ \\
\hline Lt. ear & $10(45.5), 16(51.6)$ \\
\hline Both ears & $5(22.7)$ \\
\hline \multicolumn{2}{|l|}{ Cause, n (\%) } \\
\hline Piercing & $21(95.5)$ \\
\hline Trauma & $1(4.5)$ \\
\hline Mean size $\left(\mathrm{cm}^{2}\right)$ & $0.75 \times 1.05$ \\
\hline Transvserse:longintudinal & $1: 1.4$ \\
\hline \multicolumn{2}{|l|}{ Anatomy (total=31 keloids), n (\%) } \\
\hline Lobule & $12(38.7)$ \\
\hline Helix & $17(54.8)$ \\
\hline Scapha & $1(3.2)$ \\
\hline Antihelix & $0(0.0)$ \\
\hline Postauricular & $1(3.2)$ \\
\hline \multicolumn{2}{|l|}{ Clinical type (total=31 keloids), n (\%) } \\
\hline Lobular & $14(45.2)$ \\
\hline Dumbbell & $9(29.0)$ \\
\hline Button & $5(16.1)$ \\
\hline Wrap-around & $3(9.7)$ \\
\hline Underlying disease $(n=22)$ & None \\
\hline Family history of keloids ( $n=22), n(\%)$ & $5(22.7)$ \\
\hline \multicolumn{2}{|l|}{ Accompanied symptom (n=22), n (\%) } \\
\hline Pain & $2(9.0)$ \\
\hline Pruritus & $4(18.2)$ \\
\hline Pain and pruritius & $1(4.5)$ \\
\hline None & $15(68.2)$ \\
\hline \multicolumn{2}{|l|}{ Previous treatment, $\mathrm{n}(\%)$} \\
\hline TA ILI & $6(27.3)$ \\
\hline Excision & $3(13.6)$ \\
\hline None & $13(59.1)$ \\
\hline
\end{tabular}

TA ILI: triamcinolone intralesional injection 
귀 켈로이드의 임상 형태로는 소엽 형태(lobular type) 14개 (45.2\%), 아령 형태(dumbbell type) 9개(29.0\%), 단추 형태 (button type) 5개(16.1\%), 둘러싸인 형태(wrap-around) 3개 (9.7\%)가 있었다. 고혈압, 당뇨, 신장질환이나 폐질환 등의 기 저질환을 가지고 있었던 환자는 없었다. 켈로이드 가족력이 있는 환자는 총 5 명(22.7\%)이었으며, 귀 켈로이드에 나타난 동반 증상으로는 통증을 호소하는 환자가 2명(9.0\%), 소양감 4명(18.2\%), 통증과 소양감이 같이 동반된 경우가 1명(4.5\%), 무증상이 15명(68.2\%)으로 나타났다(Table 1).

\section{켈로이드 발생 연령 및 수술 전 치료 과거력}

켈로이드 발병 평균 연령은 22.3 \pm 5.3 세였으며, 수술 전 켈 로이드에 대한 치료를 받았던 환자는 9명(59.1\%)으로, 스테로 이드 병변 내 주사 치료를 받았던 환자가 6명(27.3\%), 수술받 았던 환자가 3명(13.6\%), 치료를 받은 적이 없었던 환자가 13명 (59.1\%)이었다(Table 1).

\section{재발률 및 재발 환자와 병변의 특징}

귀 켈로이드 수술 후 22 명의 환자 31 개 수술 병변 중, 총 5 명 (22.7\%, 남 1명, 여 4명) 8 개의 병변이(25.8\%) 재발하였다. 5 명 의 환자 전부 수술 후 1 개월째 재발하였으며 기존 켈로이 드 발생 원인은 모두 피어싱이었다.

재발 환자의 평균 연령은 $26.0 \pm 4.9$ 세(최저 19세, 최대 32세) 이며, 재발된 환자의 수술 전 켈로이드 병변의 평균 크기는 $0.76 \times 1.1 \mathrm{~cm}^{2}$, 가로 직경 대 세로 직경의 평균비는 $1: 1.4$ 였으며 재발된 켈로이드의 평균 크기는 $0.76 \times 0.79 \mathrm{~cm}^{2}$, 가로 직경 대 세로 직경의 평균비는 1:1.04였다. 재발된 켈로이드의 위치는 이수(lobule) 4개(50.0\%), 이륜(helix) 4개(50.0\%)였다. 이수가 12 개 병변 중 4 개( $33.3 \%$ )가 재발하여 가장 높은 재발률을 보 였으며 이는 통계학적으로 켈로이드 위치에 따른 재발률의 차이가 있음을 보여줬다 $(p=0.0363)$. 재발된 켈로이드의 임상 형태는 아령 형태(dumbbell type)가 5개(62.5\%)로 가장 많았 으며, 소엽 형태(lobular type)가 2개(25.0\%), 둘러싸인 형태 (wrap-around) 1개(12.5\%)가 있었다. 이 중 아령 형태가 9개 병변 중 5 개 $(55.6 \%)$ 가 재발되어 가장 높은 임상 형태의 재발 률을 보였고 이 또한 다른 형태에 비해 통계학적으로 재발률 이 높음을 보여줬다 $(p=0.0358)$. 재발된 환자 5 명 중 켈로이드 병변에 동반 증상으로 통증과 소양감이 같이 동반된 경우가 1 명(20.0\%), 무증상이 4명(80.0\%)이었다. 5명의 켈로이드 재발 환자 중 켈로이드 가족력이 있었던 환자는 4명(80\%)이었으며, 그 중 2 명은 귀 켈로이드 이외의 부위(가슴, 왼쪽 어깨)에도 켈로이드가 있었다. 켈로이드 가족력은 재발과 유의미한 상관 관계가 있음을 보여줬다 $(p=0.0062)$ (Table 2).
Table 2. Characteristics of the recurred keloids and patients

\begin{tabular}{|c|c|}
\hline Characteristics & $\begin{array}{c}\text { Total } \\
(n=5, \text { keloid }=8)\end{array}$ \\
\hline \multicolumn{2}{|l|}{ Recurrence rate, n (\%) } \\
\hline Patients & $5 / 22(22.7)$ \\
\hline Keloid lesions & $8 / 31(25.8)$ \\
\hline \multicolumn{2}{|l|}{ Sex, n (\%) } \\
\hline Male & $1(20.0)$ \\
\hline Female & $4(80.0)$ \\
\hline \multicolumn{2}{|l|}{ Age (years) } \\
\hline Mean age & $26.0 \pm 4.9$ \\
\hline \multicolumn{2}{|l|}{ Cause, n (\%) } \\
\hline Piercing & $5(100)$ \\
\hline \multicolumn{2}{|l|}{ Mean size } \\
\hline Previous size $\left(\mathrm{cm}^{2}\right)$ & $0.76 \times 1.1$ \\
\hline Transvserse:longintudinal & $1: 1.4$ \\
\hline Recurred size $\left(\mathrm{cm}^{2}\right)$ & $0.76 \times 0.79$ \\
\hline Transvserse:longintudinal & $1: 1.04$ \\
\hline \multicolumn{2}{|l|}{ Anatomy (total=8 keloids), n (\%) } \\
\hline Lobule & $4(50.0)$ \\
\hline Helix & $4(50.0)$ \\
\hline Scapha & $0(0.0)$ \\
\hline Antihelix & $0(0.0)$ \\
\hline Postauricular & $0(0.0)$ \\
\hline \multicolumn{2}{|l|}{ Clinical type (total=8 keloids), n (\%) } \\
\hline Lobular & $2(25.0)$ \\
\hline Dumbbell & $5(62.5)$ \\
\hline Button & $0(0.0)$ \\
\hline Wrap-around & $1(12.5)$ \\
\hline \multicolumn{2}{|l|}{ Accompanied symptom $(n=5), n(\%)$} \\
\hline Pain and pruritius & $1(20.0)$ \\
\hline None & $4(80.0)$ \\
\hline Family history of keloids ( $\mathrm{n}=5), \mathrm{n}(\%)$ & $4(80.0, p=0.0062 *)$ \\
\hline \multicolumn{2}{|c|}{ Recurrence rate by anatomy (total=31 keloids), n (\%) } \\
\hline Lobule & $4 / 12\left(33.3, p=0.0363^{*}\right)$ \\
\hline Helix & $4 / 17(23.5, p=0.233)$ \\
\hline \multicolumn{2}{|c|}{ Recurrence rate by type (total=31 keloids), n (\%) } \\
\hline Dumbbell & $5 / 9\left(55.6, p=0.0358^{*}\right)$ \\
\hline Lobular & $2 / 14(14.3, p=0.381)$ \\
\hline Wrap-around & $1 / 3(33.3, p=0.248)$ \\
\hline
\end{tabular}

\section{고 찰}

켈로이드는 양성 종양의 일종으로 피부의 결합 조직이 비 정상적으로 증식하여 원래 모양과 다른 단단한 융기를 만들 고, 표피가 얇아져서 광택을 띠며 원래 피부색과 다른 분홍색 혹은 붉은색의 단단하고 불규칙한 모양의 구진, 결절, 판으 로 나타나는 비교적 흔한 피부과적 질환이다.) 정확한 유병률 은 현재까지 알려지지 않았으며 인종별로 대략 3 16\%까지 
문헌들마다 차이를 보이고 있으나 흑인이나 히스패닉과 같이 어두운 피부색의 인종에서 더 높다고 알려져 있다.5) 특히 귀 켈로이드는, 귀를 뚫는 피어싱에 의해 대부분 발생하여 유병 률을 확인하기 더 어렵지만 Zuber와 DeWitt ${ }^{6}$ 의 연구에 의하 면 약 $2.5 \%$ 의 유병률을 보인다고 하였다. 귀 켈로이드는 원 발 상처의 경계를 넘어 커지는 켈로이드의 특성과 눈에 잘 띄 는 귀의 해부학적 위치 특성상 미용적으로 환자의 삶의 질에 큰 영향을 주게 되어 다른 부위에 비해 적극적인 치료를 원 하는 경우가 많다.

귀의 피부는 외이도와 귓바퀴를 둘러싸고 있으며, 피부로 덮인 신축성 연골을 포함하고 있어 부드럽고 움직임이 있지 만 골막에 붙어있고 혈관 형성이 잘 이루어지지 않는 특징을 가지고 있다.' 귀 켈로이드가 발생하는 해부학적 위치를 5개 로 구분해서 환자들의 켈로이드 발생 빈도를 살펴보았다. 다 른 귀 켈로이드에 대한 문헌들과 마찬가지로 본 연구에서도 22 명 중 21명이 귀 피어싱으로 인해 발생하였기에 피어싱을 받는 위치들을 중심으로 가장 흔하게 귀를 뚫는 귓볼인 이수 (lobule), 귓바퀴인 이륜(helix), 귓바퀴 앞쪽의 평평하게 들어 간 부위인 주상와(scapha), 대이륜(antihelix), 그리고 posterior helical fold를 포함한 이후방으로 나누었다(Fig. 2). 특 이점은 가장 기본적으로 귀를 뚫는 이수에는 12 개(38.7\%)의 켈로이드가 발생한 반면, 이수에 비해 훨씬 적게 피어싱을 하 는 이륜에 17 개(54.8\%)의 켈로이드가 있었다는 것은, 이륜이 상대적으로 켈로이드가 잘 생기는 부위라는 것을 암시한다고 할 수 있다. 이는 $\mathrm{Nam}$ 등 $^{8)}$ 의 연구에서 수술한 켈로이드 환 자 20명 중 이수와 이륜에 수술받은 환자가 각각 7명씩이었 다는 것 또한 귀의 위치에 따라 켈로이드 발생률이 다르다는 것을 보여주는 예라고 할 수 있으며, 이는 부드러운 조직으로 구성되어 있는 이수에 비해 연골을 직접적으로 뚫는 이륜 피 어싱이 상대적으로 강한 외상으로써, 켈로이드를 발생시키는

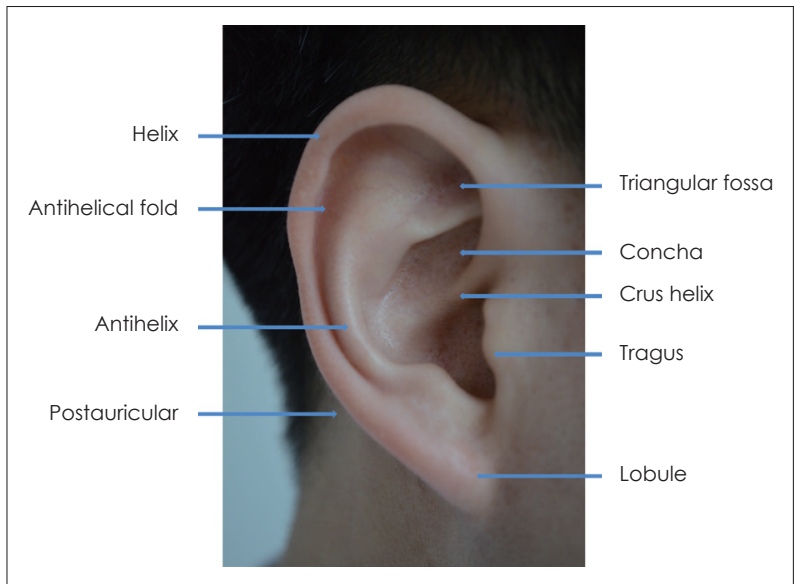

Fig. 2. Anatomy of external ear.
위험요소가 됨을 알 수 있다. 추후 귀 위치에 따른 발생 빈도 와 유병률을 조사해 보는 것도 필요할 것으로 보인다.

Park 등 ${ }^{9}$ 의 연구에서 1027 개의 이수 켈로이드를 5가지 임 상 형태학적 모습인 목 있는 형태(pedunculated), 단일결절 혹은 다수결절의 목 없는 형태(single nodular or multi nodular sessile), 파묻힌 형태(buried), 그리고 혼합된 형태(mixed) 로 나누어 Chang-Park classification을 제시하였으며, 형태 에 따라 다르게 사용한 수술법 4가지를 소개하였다. 위의 형 태학적 구분이 유용하지만 이는 이수(earlobe)에만 국한된 방 법으로 본 연구에서는 이수 이외에도 이륜, 대이륜, 이후방을 포함한 전체 귀를 대상으로 하였기에 소엽 형태(lobular type), 아령 형태(dumbbell type), 단추 형태(button type), 둘러싸인 형태(wrap-around)로 나누었으며 이는 임상적으로 귀 켈로 이드의 모습을 보았을 때 쉽게 구분할 수 있고 흔히 분류하 는 형태학적 모습이다(Fig. 3). 아령 형태는 앞뒤로 피어싱을 한 위치에 켈로이드가 발생한 것으로 31개 중 9개(29.0\%)로 2 번째로 많은 형태이며 Park 등 ${ }^{9}$ 의 연구에서 제시한 혼합된 (mixed) 형태로 볼 수 있고 이는 $80 \%$ 이상에서 이수 앞쪽으
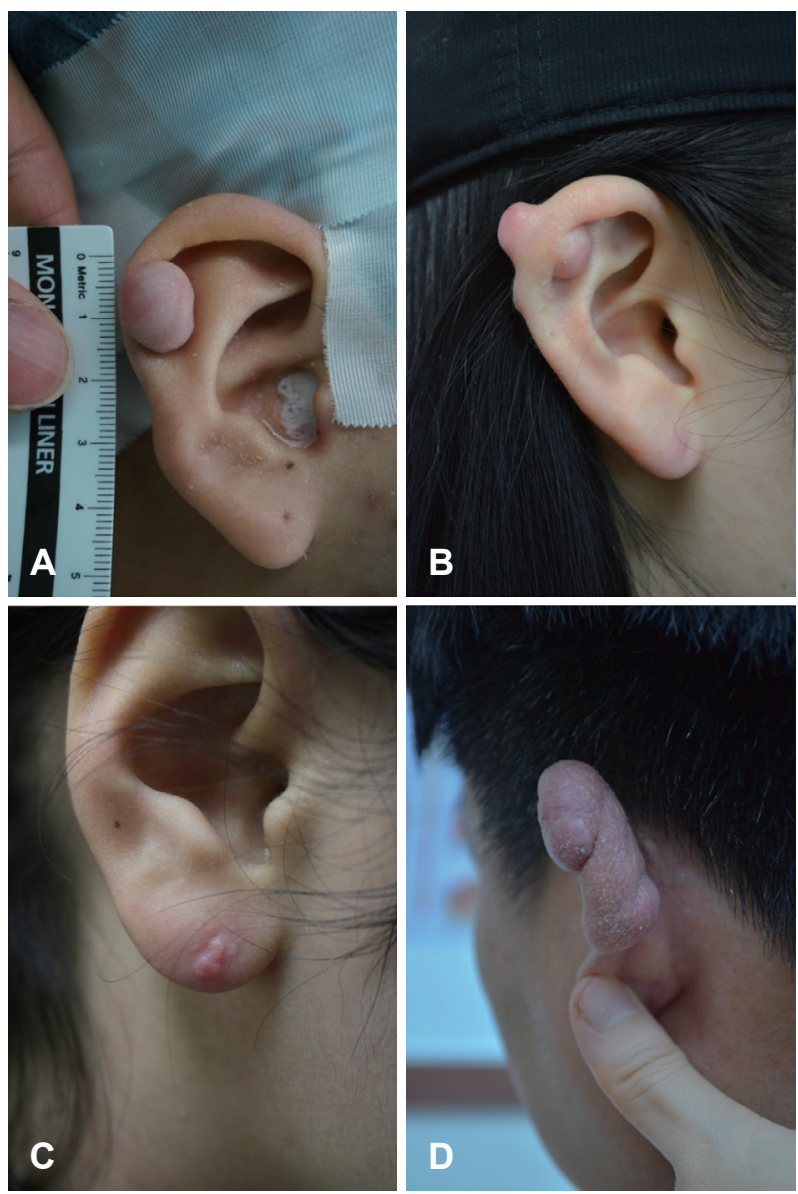

Fig. 3. Clinical type of the keloids. Lobular type (A). Dumbbell type (B). Button type (C). Wrap-around type (D). 
로는 단추 형태 혹은 파묻힌 형태를 보이고, 뒤쪽으로는 목 있는 결절 형태를 보인다고 하였다. 본 연구도 이수에서는 위 와 같은 앞뒤의 비대칭적인 아령 형태를 띄었으나, 이륜에서 는 앞뒤로 거의 같은 크기의 목 있는 소엽 형태로 아령과 아 주 흡사한 대칭적 모습을 띠어 귀 위치에 따른 아령 형태의 모습 차이가 관찰되었다. 또한 이륜의 아령 형태는 좌우도 거 의 대칭으로 구슬과 같은 구 형태를 띠었으며, 이는 단일 소엽 형태가 보통 세로로 $40 \%$ 정도 길었던 모습과 차이가 있었다. 전체적으로는 소엽 형태가 14 개(45.2\%)로 가장 흔했으며 단추 형태와 빈도를 합했을 경우 $60 \%$ 가 넘어, 이는 귀 켈로이드가 피어싱으로 인해 발생하지만 꼭 앞, 뒤 양쪽으로 과증식이 일 어나지 않고 더 많은 빈도에서 한쪽으로만 과증식이 일어난 다는 것을 볼 수 있었다. 켈로이드의 발생 기전 중, 회복 중인 상처에 장력이 가해지고 비정상적인 아교질 형성과 정렬이 섬 유모세포 증식과 아교질 형성을 촉진한다는 가설 및 여러 성 장인자의 높은 활성도가 병인에 관여한다는 것으로 알려져 있는데 이러한 활성이 앞, 뒤 방향과는 크게 관련 없이 한쪽 으로 지속적인 과증식의 이상반응이 일어난다는 것을 생각 해 볼 수 있다. ${ }^{10)}$ 또한 귀 켈로이드의 크기에 대한 가로 직경 대 세로 직경의 평균비가 1:1.4로 세로 길이가 약 $40 \%$ 정도 더 긴 모습을 볼 수 있었는데 이것 또한 과증식의 반응이 일 어나면서 중력의 영향을 받아 세로로 더 커지는 것과 귀의 형태상 세로로 더 길어 섬유모세포와 아교질의 형성이 피부 를 따라 세로쪽으로 좀 더 발생하는 것이라 생각된다.

켈로이드의 치료는 크게 비수술적 치료와 수술적 치료로 나눌 수 있으며, 스테로이드 병변 내 주사 치료가 현재까지 가 장 흔히 사용하는 치료 방법이며 다른 치료 방법들 또한 단 독 혹은 병용하여 사용할 수 있다. 스테로이드 병변 내 주사 치료의 경우에 50 100\%의 치료 효과를 보이고 재발, 피부 위축, 색소침착 혹은 색소저하 등의 부작용을 동반할 수 있 다. ${ }^{11)}$ 수술적 방법으로는 단순 절제술(simple excision), 쐐기 절제술(wedge resection), 면도 절제술(shaving excision)을 시행하거나, 절제술 후 전층 식피술(full thickness skin graft) 등이 시도되었다. ${ }^{2)}$ 본 연구에서 시행한 필렛피판(fillet flap) 은 귀의 켈로이드 주변 피부를 아주 얇게, 거의 표피층만 남 도록 박리하여 중심부를 완전 절제하고 박리된 피부를 피판 으로 만들어 다듬은 후 절제부를 덮은 후 프롤린(prolene) 6-0 실로 단순 봉합을 시행한 수술 방법으로 최근 켈로이드 수술에서 많이 사용되지만 여러 문헌들에서 명칭을 비슷하 게 사용하는 것을 경험하였다. Choi 등 ${ }^{12}$ 에서 사용한 부분층 자가피부이식(split thickness saved autograft)이나 Lee 등 ${ }^{13)}$ 의 병변 내 절제술 후 부분층 피판(intramarginal excision and split-thickness saved flap), Lee 등 ${ }^{14}$ 의 켈로이드 린드피 판(rind flap), Kim 등 ${ }^{15}$ 에서 필렛피판(fillet flap)이란 명칭이 사용되었지만 비슷한 수술 방법으로 가장 중요한 점은 켈로 이드의 중심부를 절제하는 핵 절제술(core excision)이다. ${ }^{13)}$ 이러한 여러 명칭을 통일할 필요가 있을 것으로 보인다.

본 연구에서 재발 환자는 22명의 환자, 31 개 수술 병변 중 총 5명(22.7\%), 8 개의 병변이(25.8\%) 재발하였는데 이는 비슷 한 수술법인 병변 내 절제술을 시행한 다른 문헌들과 비슷하 거나 약간 높은 재발률을 보였다. 이는 다른 문헌들에서 시행 한 병합 요법을 사용하지 않아 생긴 차이점일 수도 있지만, 저자들이 경험한 바에 의하면 재발에 있어서 중요한 것은 수 술 시 얼마나 최대한 표피층만 남기고 나머지 켈로이드 병변 을 잘 벗겨내느냐가 핵심 포인트로 생각된다. 약간의 섬유성 병변만 남겨져도 켈로이드 병변은 쉽게 재발하는 모습을 볼 수 있었다. 이는 Chong 등'6)의 연구에서 증식성 핵(proliferating core)을 얼마만큼 완벽하게 제거하느냐가 수술 후 재발 여부에 아주 큰 연관성이 있다고 하였으며, 87 개의 켈로이드 중 수술 절제 가장자리면에서의 증식성 핵이 없는 경우에는 재발이 없었다고 보고한 것과 같은 맥락으로 보인다.

Jiao 등 ${ }^{17)}$ 의 연구에서 켈로이드의 진피를 3 개의 층으로 구 분하여, 얕은 진피층(superficial dermis)은 활성화된 섬유모 세포와 림프구들이 깊게 침투되어 있으며, 중간 진피층(middle dermis)은 치밀한 세포외 기질과 많은 수의 섬유모세포가 특징적이며 깊은 진피층(deep dermis)은 세포가 드물게 있고 유리질의 콜라겐 다발들로 이루어져 있으며, 이 중 얕은 진피 층의 증가된 섬유모세포가 콜라겐을 형성하여 켈로이드 병변 을 발생시키는 것으로 보았다. 수술 시에는 최대한 표피층만 남기는 것을 목적으로 아주 얇게 박리하기에 남아 있는 피판 두께를 육안으로 측정하는 것만으로는 재발을 예상하는 것 은 어려울 것으로 생각되며 본 연구에서는 시행하지 못한 남 겨진 피판 두께와 재발의 상관관계를 연구해 보는 것이 필요 할 것으로 보인다. 상부 진피층에 남아 있는 다수의 림프구와 섬유모세포가 그룹지어 침투되어 있는 부분까지 완전히 제거 가 되었는지 여부가 재발 여부를 결정짓는 것으로 보이며 본 수술 방법으로는 켈로이드 변연에 대한 병리조직학적 평가가 어려웠으며 본 연구의 재발군과 비재발군 간에 병리조직학적 으로 차이가 없었다.

이번 연구에서 귀 켈로이드 재발은 귀 위치 중, 이수에서 12 개 병변 중 4 개(33.3\%), 이륜 17 개 중 4개(23.5\%)가 재발하 였으며 이는 이수에서 다른 귀 위치보다 통계학적으로 유의 미하게 높은 재발률을 보였다 $(p=0.0363)$. 재발된 임상적 형 태로는 아령 형태가 9 개 중 5 개(55.6\%), 소엽 형태가 14개 중 2개(14.3\%), 둘러싸인 형태가 3개 중 1개(33.3\%)였으며 아령 형태가 다른 임상적 형태보다 통계학적으로 유의미하게 높은 
재발률을 나타냈다 $(p=0.0358)$. 또한 켈로이드 가족력은 재발 과 유의미한 상관관계가 있어 $(p=0.0062)$ 수술할 환자 중 가 족력이 있는 환자는 더욱 재발 가능성이 높은 것을 알려줄 필 요가 있을 것으로 보이며 수술 외의 방법을 권하는 것도 좋 을 것으로 생각된다.

본 연구는 후향적으로 환자의 의무기록과 수술 전후의 사 진을 비교하며 진행되었으며 재발하여 재내원한 환자 외에는 유선을 통해 재발 여부를 확인하였기에 개인 간의 재발 여부 기준이 다를 수 있으며 회상 치우침(recall bias)이 발생할 수 있다. 또한 단일 기관 연구로 진행되었기 때문에 표본선정 편 파(selection bias) 등이 있을 수 있으며, 수술은 개인적인 차 이가 있어 같은 수술 방법을 사용하더라도 수술자에 의해서 재발률이 달라질 수 있다는 점과 수술 전후 처치 없이 수술 만 받은 환자를 대상으로 하였기에 표본의 수가 많지 않았다 는 점을 한계점으로 둘 수 있다. 하지만 본 연구는 국내 및 국 외 문헌에서 찾아볼 수 없었던 귓볼을 포함한 귀 전체 켈로 이드만을 대상으로 필렛피판술을 사용한 역학적 연구를 진 행하였기에 추후 귀 켈로이드 수술 고려 및 역학적 분석에 도 움을 줄 것으로 기대된다.

저자들은 2010년 5월 2018년 6월까지 약 8년간 본 과에 내원하여 귀 켈로이드로 진단받고 입원하여 수술방에서 필렛 피판을 사용하여 수술을 한 22명의 환자, 31 개의 귀 켈로이 드 병변을 대상으로 역학적 연구 및 재발률을 고찰하였다. 귀 켈로이드는 대부분 피어싱 후 발생하였으며 여성이 대다수였 다. 평균 나이는 25세 정도로 젊었으며, 켈로이드 발생 위치 는 이륜이 가장 많았고 그 다음 이수, 주상와순이었다. 임상 적 형태로는 소엽 형태가 가장 많았고 아령 형태, 단추 형태, 둘러싸인 형태순이었다. 재발된 환자는 총 5 명(22.7\%), 8개의 병변이 $(25.8 \%)$ 재발하였으며, 이수와 아령 형태가 가장 높은 재발률을 보였고, 가족력 또한 재발에 있어서 중요한 위험요 소로 나타났다. 병합 요법을 사용하지 않고 시행한 필렛피판 을 이용한 수술만으로도 재발률이 크게 높지 않아 효과적이 고 유용한 수술 방법으로 생각된다.

\section{Acknowledgments}

This study was supported by research fund from Chosun University, 2018.

\section{Author Contribution}

Conceptualization: Min Sung Kim. Data curation: Choong Jae Kim. Formal analysis: Hoon Choi. Funding acquisition: Chan Ho Na. Investigation: Bong Seok Shin. Methodology: Min Sung Kim. Project administration: Choong Jae Kim. Resources: Chan Ho Na. Software: Hoon Choi. Supervision: Bong Seok Shin. Validation:
Hoon Choi. Visualization: Chan Ho Na. Writing_original draft: Choong Jae Kim. Writing — review \& editing: Min Sung Kim.

\section{ORCIDs}

Min Sung Kim

Choong Jae Kim

Hoon Choi

Chan $\mathrm{Ho} \mathrm{Na}$

Bong Seok Shin

https://orcid.org/0000-0002-8102-6653

https://orcid.org/0000-0001-5651-7568

https://orcid.org/0000-0001-8514-3550

https://orcid.org/0000-0001-5259-5382

https://orcid.org/0000-0001-9618-1763

\section{REFERENCES}

1) Murray JC. Keloids and hypertrophic scars. Clin Dermatol 1994; 12(1):27-37.

2) Park DJ, Cha YC, Lee SJ, Na GY, Kim DW, Chung SL. The earlobe keloid treated by compression therapy with earring after shave excision. Korean J Dermatol 2002;40:1384-8.

3) Kim HJ, Jung SK, Lee KG, Kim JH, Kim IH. A comparative study on recurrence of earlobe keloids after postoperative adjuvant therapy. Korean J Dermatol 2012;50(9):768-72.

4) Kim SY, Kim JS, Park G, Oh JW, Shin JH, Kang GY, et al. Epidermal and adnexal nevi and tumors. In: Korean Dermatological Association, editor. Dermatology. 6th ed. Seoul: Daehan Medical Book Publishing;2014:815-7.

5) Ketchum LD, Cohen IK, Masters FW. Hypertrophic scars and keloids. A collective review. Plast Reconstr Surg 1974;53(2):140-54.

6) Zuber TJ, DeWitt DE. Earlobe keloids. Am Fam Physician 1994; 49(8):1835-41.

7) Sand M, Sand D, Brors D, Altmeyer P, Mann B, Bechara FG. Cutaneous lesions of the external ear. Head Face Med 2008;4:2.

8) Nam JH, Choi YJ, Kim TH, Lee GY, Park SH, Kim WS, et al. A study on intra-lesional excision of keloids. Korean J Dermatol 2009;47(6):641-8.

9) Park TH, Seo SW, Kim JK, Chang CH. Earlobe keloids: Classification according to gross morphology determines proper surgical approach. Dermatol Surg 2012;38(3):406-12.

10) Al-Attar A, Mess S, Thomassen JM, Kauffman CL, Davison SP. Keloid pathogenesis and treatment. Plast Reconstr Surg 2006; 117(1):286-300.

11) Ledon JA, Savas J, Franca K, Chacon A, Nouri K. Intralesional treatment for keloids and hypertrophic scars: A review. Dermatol Surg 2013;39(12):1745-57.

12) Choi HG, Seo SJ, Hong CK. Earlobe keloid treated by autograft after excision and immediate corticosteroid intrawound injection. Korean J Dermatol 1999;37(11):1694-6.

13) Lee NY, Song WK, Whang KK. A review of treatments of keloids with intramarginal surgical excision and postoperative irradiation to prevent recurrences. Ann Dermatol 2004;16(4):145-52.

14) Lee Y, Minn KW, Baek RM, Hong JJ. A new surgical treatment of keloid: Keloid core excision. Ann Plast Surg 2001;46(2):135-40.

15) Kim DY, Kim ES, Eo SR, Kim KS, Lee SY, Cho BH. A surgical approach for earlobe keloid: Keloid fillet flap. Plast Reconstr Surg 2004;113(6):1668-74.

16) Chong Y, Kim CW, Kim YS, Chang CH, Park TH. Complete excision of proliferating core in auricular keloids significantly reduces local recurrence: A prospective study. J Dermatol 2018;45(2):139-44.

17) Jiao H, Zhang T, Fan J, Xiao R. The superficial dermis may initiate keloid formation: Histological analysis of the keloid dermis at different depths. Front Physiol 2017;8:885. 